Yayın Geliş Tarihi: 15.02.2019

Yayına Kabul Tarihi: 26.07.2019

Online Yayın Tarihi: 26.03.2020

http://dx.doi.org/10.16953/deusosbil.527826
Dokuz Eylül Üniversitesi

Sosyal Bilimler Enstitüsü Dergisi

Cilt: 22, Say1: 1, Y11: 2020, Sayfa: 199-213

ISSN: 1302-3284 E-ISSN: 1308-0911

Araştırma Makalesi

\title{
SELÇUKLU DAMADI EBÛ KÂLÎCÂR TACÜLMÜLÛK HEZÂRESB VE FAALIYYETLERİ
}

$\ddot{O} z$

Ömer TOKUŞ

Selçuklular Dandanakan Savaşı'ndan sonra batıya doğru ilerleyişlerini hızlandırarak on yıldan az bir sürede Anadolu kapılarına ve Bilâd-ı Şâm'a kadar ulaşmışlardır. Söz konusu fetih hareketleri esnasında hâkim oldukları şehirlerin yönetimini belirli yükümlülükleri yerine getirmeleri şartıyla eski yöneticilere bırakmışlardır. Bu şekilde hâkimiyet alanlart içinde otoritelerini güçlendirmiş hem de mevcut yöneticilerin tecrübe ve kabiliyetlerinden istifade etmişlerdir. Basra Körfezi kıyısında İran ve Irak topraklart içinde bulunan Hûzistân, Vâsıt, Basra, Şîrâz ve Errâcân gibi şehirlerin idaresi de Hezâresb b. Bengîr adında mahalli bir idarecinin hâkimiyeti altında bulunuyordu. Tuğrul Bey, 447 (1055) yılında Bă̆dat'a geldikten sonra mezkûr şehirlerin idaresini eskiden olduğu gibi Hezâresb'e birakmıştır. Selçukluların hâkim oldukları coğrafyadaki siyasî ve idarî yapılarını ve hâkimiyetlerini kolaylaştıran amilleri anlayabilmek için, Selçuklu ordusunda komutanlık yapan mahalli idarecilerin rolünü tespit etmek elzemdir. Bu çalışmada Selçukluların Iran ve Irak coğrafyalarında gerçekleştirdikleri fetihlerde bulunan, fetihler esnasında gösterdiği kahramanlık ve sadakatten dolayı Tuğrul Bey ve Alp Arslan dönemlerinde taltif edilen Hezâresb b. Bengîr adlı Selçuklu komutanının faaliyetleri ve Selçuklular ile münasebetleri üzerinde durulmuştur. Selçuklu fetihlerinde yer alan mahalli emîrlerin faaliyetlerini tespit etmenin Selçuklu hâkimiyetinin fethedilen şehirlerdeki devamlılı̆̆ hakkında ipuçları verebileceği kanaatindeyiz.

Anahtar Kelimeler: Selçuklular, Hezâresb, Tuğrul Bey, Alp Arslan, Hûzistân.

\section{ABU KALICAR TAC AL-MULUK HAZARASB, A SELJUK'S GROOM, AND HIS ACTIVITIES}

\section{Abstract}

After the Battle of Dandanakan, the Seljuks accelerated their progress towards the West and reached the Anatolia gates and Bilad al-Sham region in less than a decade. During the conquering movements in question, they left the cities to the former rulers on

Bu makale için önerilen kaynak gösterimi (APA 6. Sürüm):

Tokuş, Ö. (2020). Selçuklu damadı Ebû Kâlîcâr Tacülmülûk Hezâresb ve faaliyetleri. Dokuz Eylül Üniversitesi Sosyal Bilimler Enstitüsü Dergisi, 22 (1), 199-213.

* Dr. Öğr. Üyesi, Bingöl Üniversitesi, Fen-Edebiyat Fakültesi, Tarih Bölümü, ORCID: 0000-0001-9788-8920, otokus@bingol.edu.tr 
condition that they fulfilled certain obligations. In this way, they strengthened their authority within the areas of dominance and benefited from the experience and capabilities of the current managers. The administration of cities such as Vasit, Basra, Shiraz, Arracan and Khuzistan, located in Iran and Iraq on the Persian Gulf Coast, was under the domination of a local administrator Hazarasb b. Bangir. After arriving in Baghdad in 447 (1055), Tugrrul Bey left the administration of the cities to Hazarasb as it used to be. To understand the political and administrative structures of the Seljuks in the conquered geography and the factors that facilitate their domination, it is essential to determine the role of local administrators who were commanding the Seljuk Army. In this study, the activities of the Seljuk commander called Hazarasb b. Bangir conquering the regions of Iran and Iraq, and awarded because of bravery and loyalty during the reign of Tughril Beg and Alp Arslan were emphasized. We believe that determining the activities of the local governments in the Seljuk conquests could give clues about the continuity of the Seljuk domination in the conquered cities.

Keywords: Seljuks, Hazarasb, Tughril Beg, Alp Arslan, Khuzistan.

\section{GİRIŞ}

Selçukluların Orta ve Batı İran fetihlerinden sonra hâkimiyet kurdukları alanlarda kendilerinden önceki idarecilerin yönetimlerini Selçuklu üstünlüğünü kabul etmeleri şartıyla sürdürmelerine izin verdikleri bilinmektedir. Köymen'in tabi devletler (vassal) şeklindeki tasnifi ile Selçuklu idarî yapısında yeni bir yönetim tarzı da ortaya çıkmıştır. Söz konusu idareciler Selçuklu hükümdarının metbûluğunu Selçukluların gücünden çekindikleri için kabul etmekteydiler. Hezâresb'in de dâhilinde bulunduğu tâbi idarecilerin yıllık vergi vermek, sultan adına hutbe okumak ve sikke darp etmek, Selçuklu sarayında rehine bulundurmak ve gerektiğinde ordu göndermek gibi bir takım mükellefiyetleri bulunmaktaydı (Köymen, 1976: 22-32). Selçukluların İran ve Irak hâkimiyetlerinden önce de Hûzistân ${ }^{1}$, Basra, Vâsıt ve Ahvâz gibi şehirlerin yönetimini uhdesinde bulunduran

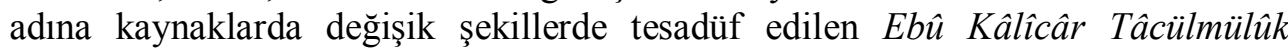
Hezâresb $b$. Bengîr $b$. Iyâd tâbi bir hükümdar olarak hâkimiyetini sürdürmeyi başarmıştır². Selçuklu idarî yapısının bir cüzü olan Hezâresb, vefatına kadar

${ }^{1}$ Hûzistân (خوستان): Irak ve Fars toprakları arasında bir geçiş güzergâhı olup, Tuster,
Ahvâz, Sûs, Basınna, Cündisâbûr, Asker Mükrem, Ramhürmüz, Devrak, Mettût, Bizân,
Karyetü'r-Reml, Karha, Lur, Beyrut, An ve İzec gibi önemli şehirleri bulunmaktaydı.
Bölgenin sinırları Fars ve Isfahân'dan başlayarak Cibâl sınırından Vâsıt'ı geçerek kare
şeklini almaktadır bkz. Mukaddesî, 2015: 418-432; İstahri, 2015: 96-105.
2 Hezâresb'in adının; Hezâresb b. Benkîr b. Iyâd el-Kürdî (İbnü'l-Cevzi, XVI, 1992: 3),
Ebû Kâlîcâr Hezâresb b. Yengîr b. İyâd (İbnü’l-Adîm, VI, ty.: 2754), Ebû Kâlîcâr
Tâcülmülûk Hezâresb b. Sekîr b. İyâş el-Kürdî (Sibt İbnü'l-Cevzî, XII, 2013: 478),
Hezâresb b. Şükr b. İyâd el-Kürdî, Hezâresb b. Tenkîn (İbn Haldûn, İber, III, 1988: 569;
IV, 361), Hezâresb b. Tengîr b. İyâd Ebû Kâlîcâr Tâcülmülûk el-Kürdî (Safedî, XXVI,
2000: 49) gibi farklı yazımlarının olduğu görülmektedir. Bazı kaynaklarda Hezâresb için
İzzüddevle unvanının yanı sıra el-Lurî şeklinde izafiyet de kullanılmıştır (Fettâh-Selim, 
öncelikle Tuğrul Bey ardından da Alp Arslan dönemlerinde Selçuklular ile birlikte el-Cezîre ve Irak bölgesindeki siyasî ve askerî faaliyetlerin içinde yer almış ve Alp Arslan'ın kız kardeşi ile evlenmek suretiyle Selçuklular ile akrabalık tesis edebilecek bir konuma erişmiştir.

\section{HEZÂRESB'IN SELÇUKLU HÂKIMIYETINE GİRIŞİ VE FAALIYETLERI}

Hezâresb'in Hûzistân, Basra, Vâsit ve Ahvâz çevresindeki hâkimiyetinin ne zaman başladığı bilinmemekle birlikte Ahvâz'ın da içinde bulunduğu Dinever, Nihavend, Berûcird, Esedâbâd ve Sâbûr-hâst gibi şehirlerin hakmiyetinin Bedr b. Hasanveyh'in 405 (1014-1015) y1lındaki ölümüne kadar Hasanveyh Kürtlerinin idaresi altında olduğu anlaşılmaktadır (İbnü'l-Esîr, VII, 1997: 597; Türkçe trc. IX, 1991: 198; Mer'̂̂, 2005: 193-194). Mezkûr tarihte "en-Nâsır" lakabına malik Ahvâz hâkimi Ebu'l-Hasan b. Iyâd'ın vefat ederek yerine oğlu Bengîr'in geçtiğine dair bilgiden yola çıkarak Hezâresb'in babası Bengîr'in 405 (1014-1015) yılında Ahvâz'ın idaresini uhdesine aldığını söyleyebilmek mümkündür. Ancak söz konusu nesep zincirinde Bengîr'in Ebu'l-Hasan b. Iyâd'in oğlu şeklinde zikredilmesi onun Iyâd'ın torunu olabileceği ihtimalini de ortaya koymaktadır. İbnü'd-Dübeysî ve Zehebî'nin Hezâresb'in adını Hezâresb b. Iyâd şeklinde aktarmasında da anlaşılacağı üzere bazen nesep zincirlerinde kısaltmalara gidildiğinin bilinmesi söz konusu muğlaklığı gidermektedir (İbnü'l-Esîr, VII, 1997: 600; Türkçe trc. IX, 1991: 200; İbnü'd-Dübeysî, I, 1974: 268; Zehebî, X, 2003: 829).

Hezâresb'in adına ilk defa 443 (1051) yılı olayları içinde tesadüf edilebilmektedir. Söz konusu tarihe kadar babası Bengîr'in adının zikredilmemesi önemli bir rol üstlenmediğine ve 443 (1051) yılından önce idareyi oğlu Hezâresb'e bıraktığına delalet etmektedir. Hezâresb, Ebû Mansûr b. el-Melik Ebû Kâlîcâr ile birlikte hareket ederek 443 (1051) yılında Büveyhî Emîri el-Melikürrahim (10481055) ile yapılan savaşta bulundu. Bu hadisede el-Melikürrahim'in gönderdiği birlikler Şîrâz'1 ele geçirmiş ve akabinde de bizzat harekete geçen el-Melikürrahim, Ahvâz'a kadar ulaşarak şehri almaya muvaffak olmuştu. Bu sırada mağlup olan Ebû Mansûr, Hezâresb ve yanında bulunanlar da Tuster'den uzaklaşarak İzec'e gitmek zorunda kaldılar. Müttefikler, el-Melikürrahim' in karşısında uğradıkları mağlubiyetten sonra Isfahan'1 ele geçiren Tuğrul Bey'e haber göndererek ondan yardım istediler ve onun hizmetine girdiler. Yardım talebini duyan el-Melikürrahim ile birlikte hareket eden el-Besâsîrî, Nûruddevle Dübeys b. Mezyed, Araplar ve Kürtler onu yalnız bıraktılar. Bunun üzerine Ebû Mansûr ve Hezâresb, Rebiyülahir 443 (Ağustos 1051) yılında Ahvâz önlerine gelerek iki gün boyunca savaştıkları elMelikürrahim'i mağlup ederek şehrin idaresini yeniden ele geçirdiler (İbnü'l-Esîr,

2014: 387). El-Lurî şeklindeki izafet Isfahân ve Hûzistân arasında Cibâl'de mukim Lur kabilesine mensubiyetine delalet etmektedir bkz. Biçer, 2014: 182. 
VIII, 1997: 92-95; Türkçe trc. IX, 1991: 434-436). Bu hadise ile Hezâresb'in Selçuklular ile ilk münasebetlerinin başladığını ve Selçuklulara bağlılığını izhar etiğini kabul edebiliriz.

Ahvâz'dan sonra Basra ve Errâcân gibi şehirlerin de Büveyhî Emîri elMelikürrahim'in istilasına uğramasıyla İzec hâkimi Hezâresb ve elMelikürrahim'in kardeşi olan Basra Emîri Ebû Ali korkuya kapılarak 445 (10531054) yılında Tuğrul Bey'in yanına gittiler. Her iki emiri iyi karşılayan Tuğrul Bey, ihsan ve ikramlarda bulunduktan sonra onlara yardım vaadinde bulundu. Böylece Tuğrul Bey, 446 (1054-1055) yılında Ebû Ali’yi Oğuzlardan müteşekkil bir ordu ile Hûzistân üzerine gönderdi. Ahvâz önlerine ulaşan Oğuzlar anlaşma ile şehri ele geçirmelerine rağmen yağma faaliyetlerinde bulundular. Bunu takip eden yıl içinde de (447/1055) Tuğrul Bey, batıya doğu ilerleyerek Bağdat'1 ele geçirdi ve Muharrem 448 (Mart-Nisan 1056) tarihinde Errâcân, Basra, Ahvâz ve buralara bağlı yerleri $360^{3}$ bin dinar karşılığında Hezâresb'e ikta ederken hutbede de adına yer vermesine izin verdi. Böylece fiili olarak Selçukluların hizmetine giren Hezâresb'in tayininin Hûzistân ve Basra'da mukim Deylemîleri tedirgin ettiği anlaşılmaktadır. Deylemîler endişelerini Tuğrul Bey'e ilettiklerinde, Tuğrul Bey "Hezâresb burada uygun gördüğ̈̈ şekilde hareket eder" diyerek Hezâresb'e olan desteğini ifade etmiş ve bundan dolayı Deylemîler elleri boş bir şekilde dönmek zorunda kalmışlardır. Tuğrul Bey indinde itibarı artan ve konumu yükselen Hezâresb, 448 (1056) yılında Halife el-Kaim'in, Çağrı Bey'in kızı Hatice Arslan Hatun ile akdedilen nikâh törenine de katılmıştır (İbnü'l-Esîr, VIII, 1997: 106-107, 111-112, 120, 129, 133; Türkçe trc. IX, 1991: 445-446, 449-450, 466, 468; Sibt İbnü'l-Cevzî, XII, 2013: 259; Türkçe trc. Sevim, 1997: 3; İbn Haldûn, III, 1988: 563-564, 569).

Kutalmış'ın 448 (1056-1057) yılında el-Besâsîrî ve müttefiklerine karş1 uğradığı mağlubiyetin akabinde Musul'da Fâtımîler adına hutbe okutulmasıyla Tuğrul Bey, on üç ay on üç gün kaldığı Bağdat'tan ayrılarak Musul'a doğru hareket etti. Sultan, Tell-Tevbe'ye ulaşınca el-Besâsîrî ve müttefikleri şehri terk etmek zorunda kaldılar. Sultan da 4 Rebiyülahir 449 (10 Haziran 1057) tarihinde Musul'a girerek Dâru'l-Emâre'ye yerleşti. Sibt'ın Garsunnime'den aktardığı bilgiler Musul'un ele geçirilmesinden sonra Hezâresb'in sultan nezdindeki mevkiini de açıklığa kavuşturmaktadır. Nitekim Musul'un istirdadından sonra Sultan, şehri Hezâresb'e ikta olarak verdi. Ancak bu esnada askerlerin şehri yağmalamak için ısrar etmeleri üzerine Hezâresb, kadın ve malların korunması için Tuğrul Bey'den yardım talebinde bulundu. Bunun üzerine askerlere verecek malı kalmayan Tuğrul Bey de halkı korumak için ordugâha getirmesi hususunda Hezâresb'e emir verdi. Hezâresb de durumu halka bildirince insanlar geceleyin evlerini boşalttılar ve sabah askerler yağma için şehre girdiklerinde yağmalayacak bir şey bulamadan şehirden ayrılmak zorunda kaldılar. Askerlerin ayrılmasını müteakip halk evlerine

\footnotetext{
${ }^{3}$ Sadece İbnü'l-Cevzî (1992: XVI: 3), aynı yılda Selçuklu veziri Amidülmülk’ün 300 bin dinar karşılığında mezkûr şehirleri Hezâresb'e ikta olarak verdiğini yazmaktadır.
} 
geri döndü ve Hezâresb de onlara ihtiyaç duydukları mal ve parayı dağıttı (Sıbt İbnü'l-Cevzî, XII, 2013, s. 270-271, 283; Türkçe trc. Sevim, 1997: 13-15, 17).

Selçuklu ordusunun Musul cihetindeki ikameti uzayınca bölge halkı ile bazı sorunların yaşanmaya başladığı anlaşılmaktadır. Garsunnime'nin aktarımları 1şığında Hezâresb'in Tuğrul Bey indinde yüksek bir mevkie haiz olduğu ve önemli işlerde de kendisi ile istişare edildiği görülmektedir. Bu çerçevede Musul'da yaşanan problemler karşısında Hezâresb, Tuğrul Bey'in huzuruna çıkarak "Arap kabilelere giderek onlar ile görüşmeyi, bunun da barlş ile neticeleneceğini veya savaşma isteğini ortaya çıkaracă̆ını; ayrıca buradaki ikametin uzadı̆̆ını ve seçeceğim bin adama ile savaşa gideceğini" söyledi. Sultan da "bin adam yeterli değil ̧̈̈̈ bin adam al" dedi. Hezâresb de "bin adamın yeterli olduğunu daha fazlasının sıkıntı yaratacă̆ını söyleyerek" bin kişilik bir ordu ile harekete geçti. Hezâresb'in başında bulunduğu Selçuklu birlikleri Berkaîd cihetinde karşılaştıkları Arap kabileleri mağlup ettiler ve esirler alarak Tuğrul Bey'in yanına döndüler. Sebep oldukları kaostan ötürü ele geçirilen tutsaklar da fillerin ayaklarının altına atılmak suretiyle cezalandırıldılar. Sadece bıyıkları çıkmamış bir çocuk fil tarafindan ezilmek istenmediğinden affedildi (İbnü'l-Esîr, VIII, 1997: 139-142; Türkçe trc. IX, 1991: 474-476; Sibt İbnü'l-Cevzî, XII, 2013: 283-284; Türkçe trc. Sevim, 1997: 18; Abû'l-Farac, I, 1987: 309; İbn Haldûn, IV, 1988: 341).

Hezâresb'in Tuğrul Bey indinde vasıl olduğu konumdan dolayı el-Besâsîrî ile birlikte hareket eden Nûruddevle Dübeys ve Kureyş, Hezâresb'e başvurarak affedilmeleri için sultan nezdinde aracılık yapmasını istediler. Bunun üzerine elBesâsîrî'nin durumu halifeye bırakılmak suretiyle her iki emir affedildi. Arap kabilelerin itaat altına alınmasından sonra Tuğrul Bey, el-Besâsîrî’ye destek veren Diyâr-1 Bekr'de mukim Mervânîler üzerine yürüdü ve yakın bir yerde karargâh kurdu. Selçuklu birlikleri karargâh kurdukları bölgede yağma faaliyetlerinde bulununca Nûruddevle Dübeys ve Kureyş, Cemaziyülahir 449 (Ağustos-Eylül 1057) yılında Hezâresb ile yazışarak yapmış oldukları anlaşmaya bağlı olduklarını ve yağmanın durması için aracı olmasını istediler. Hezâresb'in girişimleri neticesinde yağma faaliyetleri durduğu gibi Mervânîlerin yanında alıkonulan Bizans'tan Tuğrul Bey'e gelmekte olan Selçuklu elçisi Ebu'l-Fazl Nâsır b. İsmail el-Alevî de serbest bırakıldı. Akabinde Mervânîler elçi ile birlikte affedilmeleri için Tuğrul Bey'e hediyeler gönderdiler. Ancak Tuğrul Bey söz konusu hediyeleri kabul etmeyerek İbrahim Yınal'a hilat, at ve 20 bin dinar ile birlikte Musul ve ona bağl1 yerlerin idaresini verdikten sonra Bağdat'a doğru yola koyuldu. Musul ve çevresine yerleşen İbrahim Yınal, Hezâresb'i Nûruddevle Dübeys ve Kureyş'e göndererek dikkatli olmaları yönünde onları uyardı (İbnü'l-Esîr, VIII, 1997: 142143; Türkçe trc. IX, 1991: 476-477; Sıbt İbnü'l-Cevzî, XII, 2013: 284-292; Türkçe trc. Sevim, 1997: 19-20; İbn Haldûn, IV, 1988: 341).

El-Cezîre bölgesindeki durumu kontrol altına alarak Musul'u İbrahim Yınal'a veren Tuğrul Bey, 25 Zilkade 449 (23 Ocak 1058) tarihinde Bağdat'a döndü. Bu sirada Errâcân, Hûzistân ve Şîrâz gibi yerlerin yönetimini uhdesinde 
bulunduran Herzâresb'in nüfuzu gün geçtikçe artmaktaydı. Şüphesiz Hezâresb'in gücünün artması bölgedeki diğer güçleri de rahatsı etmekteydi. Bundan dolayı harekete geçen Selçuklu ailesinden Resültegin ile Fûlâd, Hezâresb'in idaresi altında bulunan Errâcân'a saldırarak şehri yağmaladılar. Hâkim olduğu topraklara yönelik yapılan bu tecavüzlerden dolayı el-Cezîre'de bulunan Hezâresb, Tuğrul Bey'den izin alarak ülkesine döndü. Basra'ya ulaşan Hezâresb savaş hazırlıklarına başladı ve bu amaçla Tacüddin b. Sahta el-Alevî ve İbn Semhâ adlı bir Yahudi'den müsadere ettiği 120 bin dinarla büyük bir ordu teşkil etti. Hazırladığı ordu ile Resültegin ve Fûlâd'ın üzerine yürüdü ve onları mağlup ederek Resültegin'i de esir etti. Esir alınan Resültegin, Hezâresb ile bir anlaşma yaparak halifeye teslim edilmesini istedi. Böylece Bağdat'a gönderilen Resültegin, şehre ulaşttğında Halife, Amidülmülk'ü davet ederek Tuğrul Bey'in Resültegin hakkındaki görüşünü öğrendikten sonra onu zincire vurdurarak hapse attı (İbnü'l-Esîr, VIII, 1997: 147149; Türkçe trc. IX, 1991: 480-482; İmamüddin el-Isfahânî, 2004:189-190; Sibt İbnü'l-Cevzî, XII, 2013: 327; Turan, 1998: 136).

Tuğrul Bey Bağdat'a döndükten sonra 450 (1058) yılında hakkında çıkan isyan haberlerinden dolayı İbrahim Yınal'ı Bağdat'a davet etti. İbrahim Yınal'ın Musul'u terk ederek Bağdat'a ulaşmasından sonra 4 Recep 450 (27 Ağustos 1058) tarihinde el-Besâsîri ve Kureyş'in başında bulunduğu Fatımîler tarafindan desteklenen kuvvetler Musul'u istila ettiler. Bunun üzerine Tuğrul Bey, 26 Recep 450 (18 Eylül 1058) tarihinde Cibâl'den aldığı yardımcı kuvvetler ile Musul üzerine yürüdü. Tuğrul Bey'in ilerleyişini öğrenen el-Besâsîrî ve Kureyş ise Musul'u terk etmek zorunda kalmışlardı. Dirençle karşılaşmadan Musul'a ulaşarak şehre yerleşen Tuğrul Bey, çetin geçen kış mevsiminden dolayı askerlerini halkın evlerine yerleştirdi. Diğer taraftan da el-Cezîre bölgesindeki ahvali tebdil etmek için Nusaybin üzerine yürüdüğü sırada kardeşi İbrahim Yınal'ın isyanı ile karşılaştı. Eşi, oğlu Anûşirvân ve veziri Amidülmülk'ü Bağdat'a gönderen Tuğrul Bey, İbrahim Yınal'ı takiben Hemedân'a doğru gitti. Kardeşi İbrahim Yınal ile Hemedân'da yaptığı savaşta ricat edip Hemedân'a sığınan ve şehirde muhasara altına alınan Tuğrul Bey, eşine ve Amidülmülk'e haber göndererek yardım istedi. Ancak Halife, el-Besâsîrî tehdidinden dolayı Hatun'un ve Amidülmülk'ün Bağdat'1 terk etmesine mani olmak istedi. Bu gelişmeler üzerine Amidülmülk, Tuğrul Bey'in evlatlığ 1 Anûşirvân adına biat alamaya başladı ve başarılı olamadığ 1 için Anûşirvân, Sultan'ın yanına gitmekte olan Altuncan Hatun'a yetişerek ona mülaki oldu. Hatun'un Bağdat'ı terk etmesi üzerine zor durumda kalan Halife de Dübeys'i Bağdat'a davet etti. Bağdat'a gelen Dübeys, el-Besâsîrî'nin Bağdat'a ulaşmakta olduğuna yönelik ulaşan haberlerden dolayı halifeye "şehirden ayrılarak Vâsıt'ta bulunan Hezâresb ile bir araya gelmeyi" teklif etti. Hatta el-Besâsîrî'ye karşı ancak Hezâresb'in durabileceğini söylemesine rağmen halifeden cevap alamayan Dübeys ülkesine döndü. Diğer taraftan el-Besâsîrî ve Kureyş'in Bağdat'a doğru ilerlemekte olduğuna dair haberlerin yayılmasından sonra Amidülmülk de maddi sıkıntılardan dolayı Ahvâz'a girerek Hezâresb'e sığındı (İbnü'l-Esîr, VIII, 1197: 152-153, 157; Türkçe trc. IX, 1991: 484-486; Bundarî, 1999: 12-13; İmamüddin el- 
Isfahânî, 2004: 191; Sıbt İbnü'l-Cevzî, XII, 2013: 328-331, 332-335, 337; Türkçe trc. Sevim, 1997: 32-33; İbn Haldûn, IV, 1988: 341-342; Turan, 1998: 135; Özaydın, 2002: 554-555).

El-Besâsîrî, 6 Zilkade 450 (27 Aralık 1058) tarihinde Bağdat'a girdikten sonra Hezâresb'in hâkim olduğu Basra ve Vâsıt gibi şehirleri ele geçirerek Ahvâz üzerine yürümeyi tasarladı. $\mathrm{Bu}$ sirada gelişmeleri öğrenen Hezâresb ise elBesâsîrî'nin maiyetinde bulunan Dübeys'e 'Ebu'l-Hâris'e (yani el-Besâsîrî) herhangi bir şeyde muhalefet etmiyorum. Sahip olduğum topraklar ile Sultan'in ülkesi arasında komşuluk ve sinır var. Ne zaman itaatten çıkarsam kendimi emniyette görmem ve Tuğrul Bey'den bana gücümün yetemeyeceği şeyler gelir. Tabi sizler ile olan ilişskim de hiçbir zaman savaş olmayacak benim yapacağım en iyi şey ise sizden uzak durup Sultan ile barlş halinde olmamdir. Benden yapmam için bir şey istenecek olursa o da halifenin sarayına iade edilmesidir" şeklinde bir mektup yazarak ahvalini ortaya koymuştur (İbnü' l-Esîr, VIII, 1997: 153, 157-158; Türkçe trc. IX, 1991: 486, 489; Bundarî, 1999: 13-14; İmamüddin el-Isfahânî, 2004: 191-192; Sadreddin el-Hüseynî, 1999: 14; Sibt İbnü’l-Cevzî, XII, 2013: 337, 355; Türkçe trc. Sevim, 1997: 45). Hezâresb'in el-Besâsîrîye Dübeys ile gönderdiği mektuptan da anlaşılacağı üzere Hezâresb'in Tuğrul Bey'in gücünden çekindiği ve topraklarını emniyet altına almak için Selçuklulara tabiliğini sürdürdüğü anlaşılmaktadır.

Ancak el-Besâsîrî'nin el-Me'mûniyye'ye ulaşarak karargâhını buraya kurmasından sonra Hezâresb, oğlu Veliyüddevle Ebu'l-'Ala' b. Hezâresb'i "Mal vermek suretiyle el-Besâsîrî̀nin ordusunun Hûzistân'a dă̆llmasını önlemek ve askerlerin geri dönmesi şartlarını ihtiva eden" bir mektup ile el-Besâsîrî̀ye gönderdi. Bunun üzerine el-Besâsîrî de "Misır halifesi adına hutbe okunması ve sikke darp edilmesi" şartıyla bunu kabul edeceğini söyleyince Hezâresb bu teklifi kabul etmekten imtina etti. Görüşmelerin olumsuz seyretmesi üzerine Ebu'l-'Ala', Dübeys'e ani bir baskın yaparak geri çekilmeye zorladı. Böylece taraflar savaş için hazırlık yapmaya başladılar ve bu sırada Hezâresb, 3500 süvari ve 1000 yayadan oluşan bir ordu topladı. Hezâresb'in ordusundan sayıca daha fazla bir ordu ile harekete geçen el-Besâsîrî, karargâhını Ahvâz'ın aşağı tarafında bulunan Hezâresb'in karşısına kurdu. Her iki taraf da birbirinden habersiz bir şekilde nehrin iki yanında bulunuyordu. Bu sırada iki taraf arasında anlaşma yapmak için elçiler vasıtasıyla görüşmeler yapıldı. Söz konusu görüşmelerde "taraflardan birinin ötekinin topraklarina saldirmamasl, Muharrem 452 (Subat 1060) yllina kadar Hezâresb'in el-Mustansır adına hutbe okutması, Hezâresb'in Sultan' in askerlerine karşı kötü niyetini açıklaması ve her ikisi arasında savaş yapılmaması" hususları müzakere edildi. Görüşmeler devam etmesine rağmen nihai bir barış anlaşması yapılmadığından taraflar arasında bir hafta boyunca küçük çaplı çatışmalar oldu. Anlaşma için görüşmeler yapılırken Anûşirvân, Tuğrul Bey’den aldığı yardımc1 birlikler ile savaş alanına ulaştı ve el-Besâsîrî, Ahvâz önlerinden Vâsıt'a çekilmek zorunda kaldı. Vâsıt'ta kalarak Hezâresb ile savaşı sürdürmeyi düşünen el-Besâsîrî, 
yanında bulunan Dübeys, Ebu'l-Feth Verrâm, Ebû Mansûr ve daha başka müttefiklerinin çekilmesinden sonra Kureyş’ten yardım istemek zorunda kaldı. Ancak bu girişimden de herhangi bir netice alamadı. Bu sirada Tuğrul Bey'in Bağdat'a yaklaşmakta olduğunu öğrenen el-Besâsîrî, 6 Zilkade 451 (14 Aralık 1059) tarihinde Bağdat'1 terk etmek zorunda kalınca Hezâresb, büyük bir tehditten kurtulmuş oldu. Tuğrul Bey, Zilhicce 451 (Ocak-Şubat 1060) yılında Bağdat'a ulaştıktan sonra Bağdat'1 terk ederek Dübeys'e sığınan el-Besâsîrî üzerine birlikler sevk etti. Söz konusu birlikler el-Besâsîrî’ yi mağlup ederek öldürürken Dübeys ise Hezâresb'in aracıllı̆̆ ile Tuğrul Bey tarafindan affedildi. Sultan, el-Besâsîrî'nin ortadan kaldırılmasından sonra Bağdat ve çevresini kontrol altına almak için Vâsıt'a geldiğinde Hezâresb de ona iltihak etti. Bölgenin kontrolünün sağlanmasından sonra Tuğrul Bey yanında Hezâresb, Ebu'l-Feth b. Verrâm ve Sadaka b. Mansur gibi emirler ile Bağdat'a döndü. Nitekim Tuğrul Bey, Safer 452 (Mart 1060) yılında tertip edilen bir törenden sonra Rebiyülahir 452 (Nisan 1060) yılında Cibâl'e gitti (İbnü'l-Esîr, VIII, 1997: 158-160, 166-167; Türkçe trc. IX, 1991: 489-492, X, 27-28; Sibt İbnü'l-Cevzî, c. XII, 2013, s. 357-358, 361, 363, 369, 374-375; Türkçe trc. Sevim, 1997: 47, 60).

Tâbi bir emir olarak Hezâresb zaman zaman elçi olarak da vazifelendirilmiştir. Tuğrul Bey, 454 (1062) yılında Mervânî ve Ukaylî topraklarını kontrol altına almak için harekete geçtiğinde yolu üzerinde bulunan Hoy halkının direnişi ile karşılaş̧ı. Bunun üzerine Hezâresb ve Savtegin' in başında bulunduğu birlikler Hoy üzerine sevk edilmiş, ancak taraflar mabeyninde yapılan savaşlar neticesiz kalınca Hoy halkı Hezâresb'in eliyle Amidülmülk el-Kündürî’ye bir mektup göndererek aman dilemişti. Söz konusu talepten sonra Savtegin ve Hezâresb'i şehre davet eden Hoylular yapılan müzakereler neticesinde 3000 dinar vermeyi kabul ettiler. Şehrin ele geçirilmesinden sonra Amidülmülk el-Kündürî asileri cezalandırmak suretiyle şehrin yönetimini uhdesine aldı. Tuğrul Bey, 455 (1063) yılında el-Kaim'in kızı Seyyide ile evlenmek amacıyla Bağdat'a geldiğinde yanında bulunanlardan biri de yine Hezâresb idi. Yaklaşı iki veya üç yıl boyunca Tuğrul Bey'in yanında bulunan Hezâresb'e mezkûr izdivaçtan sonra ülkesine dönmesi için izin verildi. Evliliği müteakip Bağdat'tan Cibâl'e hareket eden Tuğrul Bey, 8 Ramazan 455 (4 Eylül 1063) tarihinde vefat ettiğinde halife el-Kaim Tuğrul Bey'den sonraki durumu görüşmek için çevrede bulunan emîrler ile birlikte Hezâresb'i de Bağdat'a davet etti (İbnü'l-Esîr, VIII, 1997: 182-184; Türkçe trc. X, 1991: 40-41; Bundarî, 1999: 24; İmamüddin el-Isfahânî, 2004: 198; Sıbt İbnü’1Cevzî, XII, 2013: 402-403, 409-410, 412, 415; Türkçe trc. Sevim, 1997: 80-82, 85; Köymen, 1976: 32).

Tuğrul Bey'in vefatından istifade etmek isteyen Hezâresb, Halife'ye mektup göndererek "kendisine melik unvanı verilmesi durumunda 100 bin dinar verebileceğini ifade etmiş" ancak halife, söz konusu bu durumun ancak Selçuklular için yapılabileceğini ifade ederek talebi geri çevirmiştir. Halife, Hezâresb'e gönderdiği mektupta "ülkesini işgal etmeye çalışan Kavurd ile mücadele etmesi gerektiğini ve bundan sonraki süreçte isteğini kabul edebileceğini” söylemiştir. $\mathrm{Bu}$ 
ifadelerden Halife el-Kaim'in Hezâresb'e net bir cevap vermediği ve ayrıca Kavurd'u bir tehdit olarak kabul etmek suretiyle Hezâresb'i onunla mücadeleye teşvik ettiği sonucuna varılabilir. Halife'nin bu söylemi karşında Kirman hâkimi Kavurd da Hezâresb'e; "kendine itaat etmesi halinde Hûzistân, Basra ve çevrelerinde kendi adına hutbe okutup para bastırması, bunu yapmadiğı takdirde de daima tehdit altında olacağına" dair bilgileri ihtiva eden geniş bir mektup göndermiştir (Sıbt İbnü'l-Cevzî, XII, 2013: 418; Sevim, 1997: 86-87; Güner, 2004: 52; Özaydın, 2012: 164; Piyadeoğlu, 2016: 98-99). Bu mektuplar karşısında Hezâresb'in nasıl bir tutum takındığını görebilmek mümkün olmasa da Alp Arslan'ın ortaya çıkarak Selçuklu tahtına oturmasının Hezâresb'i rahatlattı̆g 1 söylenebilir.

Tuğrul Bey'in vefatından sonra Ebu'l-Kasım Süleyman ve Kutalmış gibi taht müddeilerini mağlup ederek Selçuklu tahtına oturan Alp Arslan (1063-1072) döneminde de Hezâresb konumunu muhafaza etmiştir. Buna rağmen vergilerin ödenmemesinden dolayı tarafların zaman zaman karşı karşıya geldiği de olmuştur. Alp Arslan 1064 yılında Ani'yi aldıktan sonra Nesâ'da mukim Şebânkare Emîri Fazlûye öncelikle Alp Arslan'a bağlılığını arz ederek Kavurd'a karşı yardım talebinde bulunurken diğer taraftan da Ahvâz' da bulunan Hûzistân ve Basra hâkimi Hezâresb'e gönderdiği mektupta Şîrâz'1 Kavurd'dan almak için destek istemiştir. Söz konusu talepten sonra Hezâresb'in gönderdiği kuvvetlerle Şîrâz'a karşı saldırıya geçen Fazlûye, Kavurd'a mağlup olarak Şîâz hâkimiyetini de kaybetmiştir. Bu gelişmelerden sonra Ermîniyye seferinin avdetinde Alp Arslan, Tuğrul Bey döneminden beri Hûzistân, Basra ve Ahvâz için ödemediği vergiyi talep etmek için hâdimi Porsuk'u Hezâresb'e göndermiştir. Hemedân'dan Hezâresb'e gönderilen mektupta Hezâresb'in yanında tutuklu bulunan Sadaka b. Mezyed'in de salıverilmesi talep edilmiştir. Mektubun devamında emrin ifa edilmemesi durumunda Alp Arslan'ın bizzat Hezâresb'in üzerine yürüyeceğine dair bir tehdit de bulunuyordu. Hezâresb, mezkûr emirler doğrultusunda vergiyi göndereceğini ve Sadaka'yı da serbest bırakacağını söylemesine rağmen Alp Arslan, Hezâresb'in yönetimi altında bulunan Basra şehrini Büveyhî Ebû Ali b. Ebû Kâlîcâr'dan aldığı Kum ve Kâşan'a mukabil 1 milyon 50 bin dinar karşılığında Ebû Ali’ye verdi. Bunun üzerine Hezâresb, Alp Arslan'a gönderdiği mektupta "Ben durumumun bozulmasını gerektirecek ne yaptım? Etrafta benden başka hâkimiyet kuracak kimse kalmadl, olumsuz bir şey yapmadım" diyerek Basra üzerindeki otoritesini kaybetmek istemediğini dile getirmiştir. Bunun yanı sıra Hezâresb, Ebû Ali'ye bir mektup göndererek “Basra'nın babasının memleketi olduğunu, halkın onu sevdiğini ve bu durumun bozulmastyla telafisinin mümkün olmayacağını" söylemiştir (456/1064). Taraflar arasındaki bu yazışma neticesinde Basra ve Vâsıt gibi şehirlerde Hezâresb'in hâkimiyetinin son bulduğu, Muharrem 459 (Kasım-Aralık 1066) yılında her iki şehrin idaresinin Basra mültezimi el-Agarr Ebû Sa'd'ın ölümünden sonra 300 bin dinar karşıllı̆ında yeniden Hezâresb'e ikta edilmesinden anlaşılmaktadır. Buna rağmen Hezâresb'in Kavurd isyanı esnasında Alp Arslan'ın yanında yer alması konumunu muhafaza ettiğini göstermektedir 
(İbnü'l-Cevzî, XVI, 1992, 103; İbnü'l-Esîr, VIII, 1997: 211; Türkçe trc. X, 1991: 63; Sibt İbnü'l-Cevzî, XII, 2013: 429-430; Türkçe trc. Sevim, 1998: 11-12; Mehmet Altay Köymen, 1972: 112-113; Piyadeoğlu, 2016: 99, 127-128).

Sultan Alp Arslan 457 (1064) yılında kardeşi Kirman Meliki Kavurd üzerine yürüdügünnde Hezâresb de mezkûr orduya iltihak etmek için Şîrâz'a gitmişti. Bundan sonraki yılda da Garsunnime'nin Uyunu't-Tevârîh adlı eserinden alıntı yapan Sıbt İbnü'l-Cevzî, Hezaresb'in 458 (1065-1066) yılında Alp Arslan'ın yanında bulunduğunu ve onunla birlikte Merv'den Harezm'e gittiğini kaydetmektedir. Söz konusu bu seyahat esnasında Alp Arslan, Hezâresb’ten Tuğrul Bey döneminden kalan üç yıllık Basra, Hûzistân ve Errâcân şehirlerinin ikta borcunu talep etmiştir. Borçlu olduğu meblağı toplamak için ülkesine dönmesi gerektiğini ifade eden Hezâresb'e "parayl getirinceye kadar kapısından ayrllamayacağl” söylenmiştir. Bu konuşmalar Alp Arslan'ın Hezâresb'e karşı tutumunun menfi yönde olduğuna delalet etmektedir. Bu konuşmaların devamında Sultan bir gece vakti kendi nevbet davulundan sonra Hezâresb'in nevbet davulunun çalmasından dolayı tepki göstermiş, ancak sabah uyandığında Hezâresb'e hediyeler takdim etmek suretiyle takındığı tavırdan dolayı özrünü beyan etmiştir. Sultan, Harezm'e vardığında hadimleri onu karşılamış ve ona değerli armağanlar ve hediyeler takdim etmişlerdir. Bu armağanların arasında içinde altınların bulunduğu debîkî deriden kesedeki dinarları Sultan, önce oğlu Ayaz'a ardından da Hezâresb'e vermiştir. Ayaz, kendisine takdim edilen altınları dizlerinin üzerinde yürüyerek alırken Hezâresb, ayağa kalkarak almıştır. Bundan dolayı Alp Arslan, Hezâresb"e "senin zihninde hâkimiyet sevdası yatmaktadır, bunu gerçekleştirmek amactyla halifeyle mektuplaşıp para sarf etmektesin ve Nişabur'da Ahvâz'ı tahkim etmekle meşgul oldun" diyerek takbih etmiştir. Hezâresb, bunun üzerine özür dilerek "söz konusu âdeti bilmediğini" dile getirmiştir. Sultan bu yaşananların akabinde de Hezâresb'e gözdağı vermek için kardeşi Süleyman'ın hacibi Aytekin'in başını vurarak Hezâresb'e göndermiştir. Bunun üzerine korkuya kapılan Hezâresb, Nizamülmülk ile görüşerek Alp Arslan ile arasını yapmasını istemiş ve Nizamülmülk'ün girişimleri ile Alp Arslan, "kalbini hoş tutmasını, söylediklerinin doğru ve dürüst niyetinden tevellüt ettiğini, art niyetinin olması durumunda korkutmaya gerek duymadan onu cezalandıracağını" söylemiştir. Bu konuşmadan sonra da Alp Arslan, Hezâresb'in ülkesine dönmesine izin vereceğine dair ahitte bulunmuştur. Alp Arslan, Hezâresb'e tabl, alem, bin at, elli bin koyun ile 100 bin dinar ile mükafatlandırdıktan sonra kalan borçlarını ödemesi şartı ile ülkesine göndermiştir. Hezâresb Ahvâz'a ulaştıktan sonra ülkesinde mukim Deylemîlerin paralarını ve iktalarını müsadere etmek suretiyle büyük bir servet edinmiştir (Sıbt İbnü'l-Cevzî, XII, 2013: 442-443, 446-447; Türkçe trc. Sevim, 1998: 20-22; Mîrhând, 2015: 108-109; Köymen, 2004: 151; Piyadeoğlu, 2016: 100, 128-130). 


\section{HEZÂRESB'IIN ÖLÜMÜ}

Hezâresb, Kirman meliki Kavurd'un çıkardığı isyanlarda Nizamülmülk ile birlikte Büyük Selçuklu Devleti'nin saflarında yer almış ve Şebânkare emîri Fazlûye'nin esir edilmesinde de önemli bir rol ifa etmişti. Sebebi bilinmemekle beraber 462 (1069-1070) yılında Hezâresb'in hâkimiyet sahasında bulunan Vâsıt'ın Mezyedî Emîri Nûruddevle Dübeys'e verilmesi Selçuklular ile münasebetlerinin olumsuz bir yöne doğru evirildiğine delalet etmektedir. Hezâresb'in Mezyedî Emîri ile münasebetleri menfi olduğundan ${ }^{4}$ Hezaresb, Alp Arslan'1 Dübeys'e ait toprakları ele geçirmesi için teşvik etmekteydi. Şüphesiz bu sebepten olmalıdır ki Hezâresb 462 (1070) yılında Alp Arslan'ın huzuruna çıkmak için Isfahan'a gitti. Buradaki görüşmeden nasıl bir sonuç çıktı̆ğ bilinmemekle beraber Sibt İbnü'lCevzî'nin ifadelerine göre, 21 Ramazan 462 (3 Temmuz 1070) tarihinde Isfahan'dan ayrılarak Hûzistân'a doğru yola çıkan Hezâresb, Ferende'ye ulaştığında ishalden vefat etti. Alp Arslan'ın kız kardeşi Sâfiye Hatun ile evlenerek Selçuklular ile sıhriyet kuran Hezâresb'in sultan nezdinde itibarının, şanının ve mülkünün arttığı anlaşılmaktadır. Sultan'ın kız kardeşi ile evlendiği için kibirlendiği ve halka tasallutta bulunduğu kaydedilmektedir. Hezâresb'in Sâfiye Hatun ile izdivacının ne zaman gerçekleştiği tam olarak tespit edilememekle birlikte İbnü'l-Esîr'in 462 (1070) yılı olayları içinde bu evliliği aktarması ölümünden hemen önce gerçekleştiği izlenimini vermektedir (İbnü’l-Esîr, VIII, 1997: 218; Türkçe trc. X, 1991: 69; Sadreddin el-Hüseynî, 1999: 29-30, İmamüddin el-Isfahânî, 2004: 205; Bundarî, 1999: 35-36; Sıbt İbnü'l-Cevzî, XII, 2013: 471, 479; Türkçe trc. Sevim, 1998: 32; İbn Vâsıl, ty.: 23; Safedî, XXVI, 2000: 49; Ahmed b. Mahmud, 2011: 83-84; Müneccimbaş1, nr. 2102, vr. 346; Bezer, 2006: 95).

Hezâresb'ın vefatından sonra Mezyedî Emîri Nûruddevle Dübeys, yanına aldığı Musul Emîri Müslim b. Kureyş ile birlikte Alp Arslan'ın yanına gitti. Hemedân'a ulaşan Müslim b. Kureyş, Hezâresb'in ölümü ile dul kalan Sultan'ın kız kardeşi ile evlenmek istediğini söyledi. Bu teklifi kabul eden Alp Arslan kız kardeşini Müslim ile evlendirdi ve Müslim'e bazı iktaları vererek gönderdi. Böylece Müslim b. Kureyş'in Alp Arslan indinde Hezâresb'in konumunu elde ettiği kabul edilmektedir. Bilindiği üzere tâbi emîrler de vezir tayin etme hakkına malik olduklarından kaynaklarda tespit edilebildiği kadarıyla Hezâresb'in Ebû Ya'lâ er-Rûzrâverî el-Hüseyin b. Muhammed b. Abdullah b. İbrahim ve Ebu'l'Alâ' eş-Şîrâzî Muhammed b. el-Hasan b. el-Hüseyin adında iki veziri bulunmaktaydı (İbnü'l-Esîr, VIII, 1997: 218; Türkçe trc. X, 1991: 69; İmamüddin el-Isfahânî, 2004: 204-205; Bundarî, 1999: 33-36; Sıbt İbnü'l-Cevzî, XII, 2013: 471; Türkçe trc. Sevim, 1998: 32; İbnü'l-Adîm, VI, ty.: 2754; İbnü'd-Dübeysî, I, 1974: 268; Zehebî, X, 2003: 829). Hezâresb'in vefatından sonra onun hâkim

\footnotetext{
${ }^{4}$ Halife el-Kaim'in Hille Emîri Dübeys b. Mezyed'e gümüş eyerli at verdiğinde Dübeys'in Ahvâz hâkimi Hezâresb'e altın eyerli at verildiğini söyleyerek hediyeleri reddetmesi ikilinin münasebetlerinin iyi olmadığının göstergesidir bkz. Şeker, 1998: 24.
} 
olduğu toprakların Türk komutanlara ikta yolu ile verildiği bilinmekle birlikte Hezâresb'in ailesi hakkındaki bilgilerimiz oldukça sınırlıdır. Bununla beraber elCibâl ve el-Lur bölgesinin hâkimi olarak İmâmüddin Ebu'l-Muzaffer el-Behlivân b. Hezâresb b. Bengîr el-Lurî adında bir oğlundan da bahsedilmektedir (FettâhSelim, 2014: 387; ed-Düleymî, 2010: 95). Bu bilgiler dışında Hezâresb'in sadece yaşadığ dönemde bölgenin idaresinde bulunduğu ve ölümü ile birlikte ailenin tarih sahnesinden çekildiği anlaşılmaktadır.

\section{SONUÇ}

Irak ve İran topraklarının Selçukluların hâkimiyeti altına girmesi ile birlikte buralarda mukim mahalli emirler Selçukluların yüksek hâkimiyetini kabul etmek zorunda kalmışlardır. Yeni bir coğrafyada üstünlük kurmaya çalışan Selçuklular, hâkim oldukları bölgelerin demografik, sosyal yapısı ile kendi siyasîaskerî güçlerini de göz önüne alarak ele geçirdikleri yerlerdeki idarî yapıyı muhafaza etmek suretiyle kendi bünyelerine uyarlamaya çalıştıkları ifade edilebilir. Bu çerçevede Cibâl'den Vâsıt'a kadar uzanan Hûzistân bölgesinin yönetimini Selçuklulardan önce de uhdesinde bulunduran Hezâresb b. Bengîr, 447 (1055) yılında Tuğrul Bey'in Bağdat'ı alması ile Selçuklara tabi olmuştur. Hezâresb'in sahip olduklarını muhafazaya yönelik kaygısının da vermiş olduğu bir çekingenlikle Tuğrul Bey'e sadık kaldığını görebilmek mümkündür. Bunun sonucunda el-Cezîre bölgesinde faaliyet gösteren Selçuklu birlikleri ile birlikte hareket eden komutanlardan biri de Hezâresb olmuştur. Askerî başarılarının yanı sıra el-Cezîre bölgesindeki Arapların Tuğrul Bey ile irtibatının kısmen Hezâresb üzerinden yürütüldüğü anlaşılmaktadır. Söz konusu sadakat ve hizmetlerinden dolayı 449 (1057) yılında Musul ele geçirildiğinde şehrin Hezâresb'e verildiğini görmekteyiz. Bunların devamında İbrahim Yınal isyanının sonucunda ortaya çıkan kaotik ortamda, Bağdat'ın Selçuklu güçlerinin elinden çıkmasına ve Tuğrul Bey'in Hemedân'da İbrahim Yınal tarafindan kuşatılmasına rağmen Hezâresb'in Fatımîler tarafından desteklenen el-Besâsîrî'ye karşı direnerek sahip olduklarını koruması dikkate değerdir. Buna rağmen Tuğrul Bey'in vefatından istifade etmek isteyen emirlerden biri olan Hezâresb, Alp Arslan'1n kısa sürede duruma hakim olarak Selçuklu tahtına oturması ile Selçuklulara bağlılığını sürdürmüştür.

Alp Arslan döneminde de ayrıcalıklı konumunu muhafaza eden Hezâresb, zaman zaman ödemediği vergilerden dolayı takbih edilse de Selçuklular ile rabıtasını kesmemiştir. Bunun neticesinde Alp Arslan'ın kız kardeşi Sâfiye Hatun ile evlenerek Selçuklular ile sihriyet kurmuş ve 462 (1070) y1lında ölümünden sonra da hâkim olduğu topraklar Selçuklar tarafindan direkt olarak yönetilmeye başlanmıştır. Sonuç olarak Selçukluların hâkim oldukları coğrafyada mukim ve Selçuklulara askerî, siyasî ve ilmî açıdan hizmet etmiş emîr ve komutanların tespit edilerek müstakil bir şekilde çalışılması Selçuklu idarî yapısının inceliklerini ve maharetini belirgin bir şekilde ortaya koyacaktır. 


\section{KAYNAKÇA}

Abû'l-Farac (1987). Ab̂̂'l-Farac tarihi. c. I. (Ö. R. Doğrul, Çev.). Ankara: Türk Tarih Kurumu.

Ahmed b. Mahmud (2011). Selçuknâme. E. Merçil (Haz). İstanbul.

Alican, M. (2014). Selçuklu Veziri Amidülmülk Kündürî’nin yükselişi ve düşüşü. The Journal of Academic Social Science Studies, III (29), 237-259.

Bezer, G. Ö. (2006). "Müslim b. Kureyş”. DİA, c. XXXII, ss. 94-96.

Biçer, B. (2014). İslâm coğrafyacılarının eserlerinde Kürtler hakkındaki rivayetler (9. Yüzy1l-13. Yüzyı1). Tarih Okulu Dergisi (TOD), 7 (XVII), 165-187.

Bundarî (1999). Zübdetü'n-Nüsre ve Nuhbetu'l-Usra (Irak ve Horasan Selçukluları Tarihi). (K. Burslan, Çev.). Ankara: Türk Tarih Kurumu.

ed-Dülemî, (2010). Muhammed Hasan Süheyl, el-İktâ' fí Devleti'lAbbasiyye, Bağdat.

Fettâh, F. Y. \& Selim, L. M. (2014). "Sûretu'l-Ümerâ'i'l-Kurd fî'lMasâdıri'l-Edebiyeti'l-Arabiyye", Mecelletu Cami'ati Zâhĥ, II (II), 381-401.

Güner, A. (2004). “Melik”. DİA, c. XXIX, ss. 51-53. Şehâde, Beyrut.

İbn Haldûn, (1988). Divânu'l-Mübtedâ ve'l-Haber, I-VIII, thk. Halîl

İbn Vâs1l, (ty.). Müferricü'l-Kurûb fî Ahbâri Benî Eyyûb, c. I, thk. Cemaleddin eş-Şeyyâl, Kahire.

İbnü'd-Dübeysî, (1974). Zeylü Târîhi Medineti's-Selâm, c. I-V, thk. Beşşâr Avvâd Ma'rûf, Bağdat.

İbnü'l-Adîm, (ty.). Buğyetu't-Taleb fî Târîhi Haleb, c. I-XII, thk. Süheyl Zekkar, Daru'l-Fikr Beyrut.

İbnü'l-Cevzî, (1992). el-Muntazam fî Tarihi'l-Ümem ve'l-Mülûk, I-XIX, thk. Muhammed Abdulkadir Ata-Mustafa Abdulkadir Ata, Dâru'l-Kutubi'lİlmiyye, Beyrut.

İbnü'l-Esîr, (1997). el-Kâmil fî't-Tarih, c. I-X, thk. Ömer Abdusselam Tedmürî, Dâru'l-Kitâbi'l-Arabî, Beyrut. İstanbul.

İbnü'l-Esîr, (1991). el-Kâmil fí't-Tarih, c. IX-X, trc. Abdülkerim Özaydın,

İmamüddin el-Isfahânî, (2004). Tarihu Devleti Al-ı Selcuk, thk. Yahya Merâd, Beyrut.

İstahri, (2015). Ülkelerin yolları. (M. Ağarı, Çev.). İstanbul: Ayışı̆̆ıikitapları. 
Köymen, M. A. (1972). Alp Arslan ve zamanı. İstanbul: Başbakanlık Kültür Müsteşarlığı Kültür Yayınları. Kurumu.

Köymen, M. A. (2004). Selçuklu devri Türk tarihi. Ankara: Türk Tarih Yayınları.

Köymen, M. A. (1976). Tuğrul Bey ve zamanı. İstanbul: Kültür Bakanlığ1

Mer'̂̂, F. (2005). el-İmâretü'l-Kürdiyye fì'l-Asri'l-Abbâsî es-Sânî 350511/960-1117, Erbil.

Mîrhând, (2015). Ravzatu's-Safâ fì Sîreti'l-Enbiyâ ve'l-Mülûk ve'l-Hulefâ, trc. Erkan Göksu, Ankara. İstanbul.

Mukaddesî, (2015). İslâm coğrafyası (Ahsenü’t-Takâsîm). (A. Batur, Çev.).

Müneccimbaş1, Cami'ü'd-düvvel, Esad Efendi, nr. 2102, vr. 326-402.

Özaydın, A. (2002). "Kündürî”. DIA, c. XXVI, ss. 554-555.

Özaydın, A. (2012). "Unvan”. DIA, c. XLII, ss. 163-166.

Piyadeoğlu, C. (2016). Sultan Alp Arslan fethin babası. İstanbul: Kronik Yayınları.

Sadreddin el-Hüseynî (1999). Ahbârü'd-Devleti's-Selçukiyye. (N. Lügal, Çev.). Ankara: Türk Tarih Kurumu.

Safedî, (2000). el-Vâfì bi'l-Vefiyât, c. I-XXIX, thk. Ahmed Arna'ûd-Türkî Mustafa, Beyrut.

Sevim, A. (1998). Sıbt İbnü'l-Cevzî'nin Mir'âtu'z-Zaman fî̀ Tarihi'l-âyan adlı Eserindeki Selçuklularla ilgili bilgiler II. Sultan Alp Arslan dönemi. Belgeler, XIX (23), 1-51.

Sevim, A. (1997). Sibt İbnü'l-Cevzî'nin Mir'âtu'z-Zaman fî̀ Tarihi'l-âyan adlı eserindeki Selçuklularla ilgili bilgiler I. Sultan Tuğrul Bey dönemi. Belgeler, XVIII (22), 1-90.

Sibt İbnü'l-Cevzî. (2013). Mirâtu'z-Zamân fî Tarîhi'l-A'yân, c. I-XXIII, thk. Kamil Selman el-Cebûrî-Ahmed Zeki el-Enbârî-Kays Kazım el-Cennâbî, Beyrut.

Şeker, M. (1998). “Hil'at”. DİA, c. XVIII, ss. 22-25.

Turan, O. (1998). Selçuklu tarihi ve Türk-İslam medeniyeti. İstanbul: Ötüken Yayınları.

Zehebî, (2003). Târîhu'l-İslâm ve Vefiyâti'l-Meşâhîri'l-A'lâm, c. I-XV, thk. Beşâr Avvâd Ma'rûf, Beyrut. 
Selçuklu Damadı Ebû...

DEU Journal of GSSS, Vol: 22, Issue: 1

EK 1: Mukaddesî’ye Göre Hûzistân Bölgesi

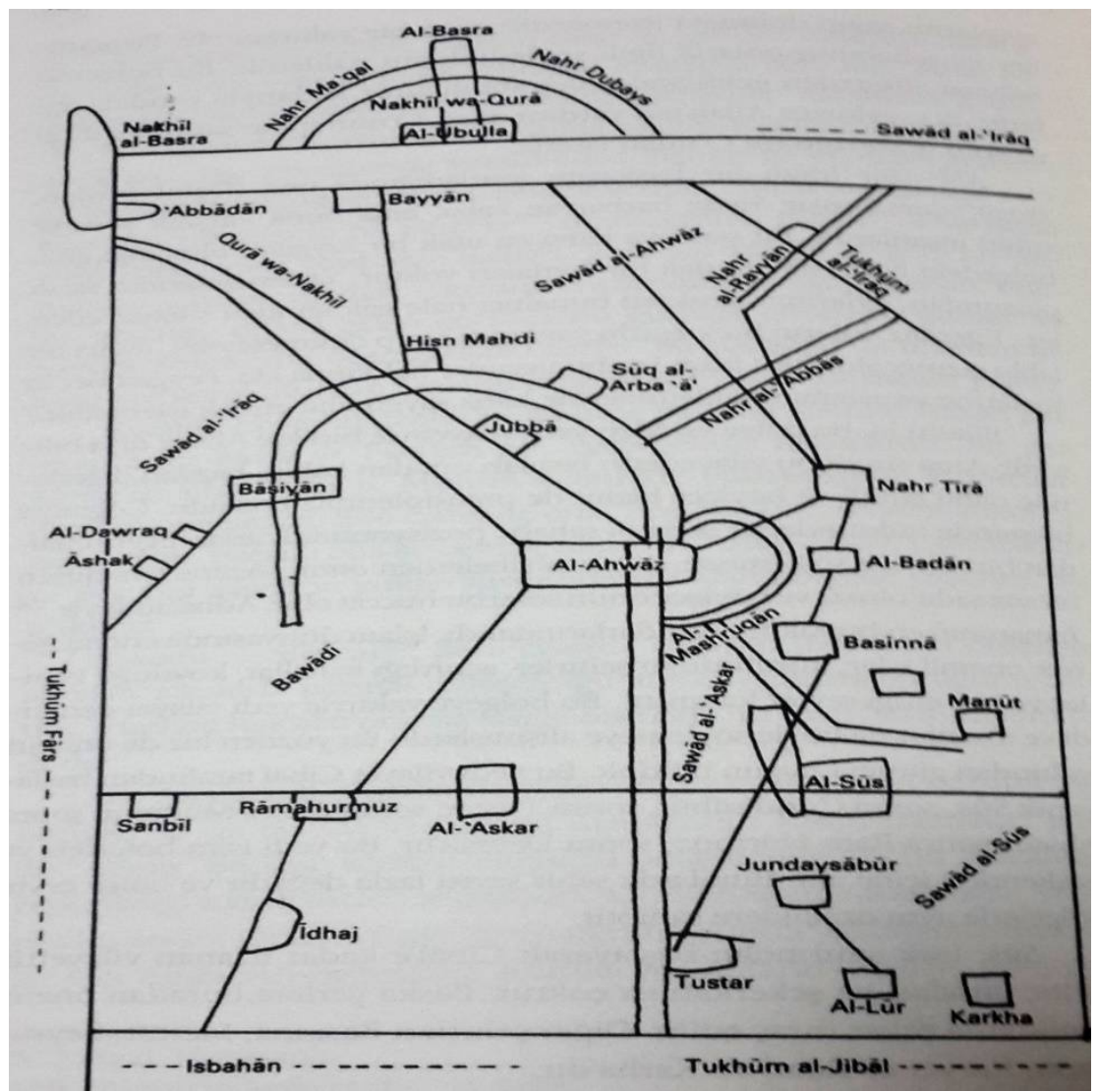

Kaynak: Mukaddesî, (2015). İslâm coğrafyası (Ahsenü't-Takâsîm). (A. Batur, Çev.). İstanbul. s. 422. 